Article

\title{
Effects of Short Fibers on the Long-Term Behavior of RC/FRC Beams Aged under Service Loading
}

\author{
Francesco Micelli ${ }^{1, *}$, Leandro Candido ${ }^{1}$, Emilia Vasanelli ${ }^{2} \oplus$, Maria Antonietta Aiello ${ }^{1}$ and \\ Giovanni Plizzari ${ }^{3}$ \\ 1 Department of Engineering for Innovation, University of Salento, via per Monteroni, 73100 Lecce, Italy; \\ leandro.candido@unisalento.it (L.C.); antonietta.aiello@unisalento.it (M.A.A.) \\ 2 Institute for Archaeological and Monumental Heritage (CNR-IBAM), via per Monteroni, 73100 Lecce, Italy; \\ emilia.vasanelli@cnr.it \\ 3 Department of Civil Engineering, Architecture, Land and Environment, University of Brescia, Via Branze 43, \\ 25123 Brescia, Italy; giovanni.plizzari@unibs.it \\ * Correspondence: francesco.micelli@unisalento.it; Tel.: +39-0832-297380; Fax: +39-0832-297248
}

Received: 16 April 2019; Accepted: 17 June 2019; Published: 21 June 2019

check for updates

\begin{abstract}
The enhanced post-cracking properties of fiber-reinforced concrete (FRC), as compared to plain concrete (PC), are extensively proven by many experimental findings. However, still limited experimental data are available on the behavior of such materials in long-term conditions and durability. This paper shows results from a study lasting for about seven years, which was for a final discussion on the behavior in the short and long-term of steel and polyester FRC beams with conventional steel reinforcement, after being exposed to sustained service loading and natural environmental agents for 72 months. After 28 days of curing in laboratory conditions, the beams were moved to the exposure site and loaded up to service conditions. The evolution of the crack pattern was monitored and recorded over time. After this long exposure the beams were subjected to a four point bending test in order to evaluate their residual mechanical behavior. Eventually, the beams were cut, in order to carry out durability tests for the evaluation of the carbonation depth and chloride penetration. The experimental results highlight the favorable effects of short fibers in reducing crack width and enhancing flexural stiffness. The presence of short structural fibers appears also to play a useful role in delaying creep effects inside the concrete beams. Finally, the experimental cracking behavior is compared with the one computed by applying the fib Model Code 2010 for the bearing capacity and crack width prediction.
\end{abstract}

Keywords: fiber reinforced concrete; cracking; service life; long-term

\section{Introduction and Research Significance}

During the past four decades, the presence of short fibers in concrete mixes has been investigated in terms of mechanical behavior and cracking [1,2] under both short and long-term loading [3-5]. It is now clear that the use of fibers is beneficial in terms of toughness and ductility under both static or dynamic loads [6-14] and blast $[15,16]$. Furthermore, the ability to undergo large inelastic deformations and shear stress reversals during seismic events is another important requirement that is fulfilled by fiber Reinforced Concrete (FRC) [17]; in fact, the enhanced tensile resistance leads to an increased shear strength of the members, especially in multi-axial stress state conditions $[18,19]$. When compared to plain concrete, FRC members show a better cracking behavior with an increased number of smaller cracks [20].

Indeed, the effectiveness of fibers in controlling the (flexural) cracking behavior of concrete depends upon several factors, such as type, geometry and the volume fraction of fibers (that govern 
the FRC toughness), as well as upon parameters that control cracking in Reinforced Concrete (RC) beams [21] as the reinforcement ratio, concrete cover, bar diameter, bar spacing, the presence of stirrups, etc. Due to the reduced crack width, FRC is expected to enhance the structural behavior, with particular reference to rebar corrosion and a consequent decay of the structure. In this perspective, FRC could be used to extend the service life of buildings, especially in aggressive environments.

Even though the mechanical response of FRC structural elements is widely studied, an accurate analytical computation of crack width and spacing in FRC flexural is still an open issue, studied in [22] for the specific case of tunnel lining, and in [23] for beams. However, although analytical or semi-analytical approaches are commonly adopted for design purposes (as in Model Code 2010 [2], Eurocode 2 [24] and ACI 224 R [25]), any relationships able to predict crack widths in FRC elements require further validation or assessment.

Design equations for FRC members are expected to be as similar as possible to those available for the RC elements. Referring to crack opening and distance, RILEM TC 162 TDF [26] and MC2010 [2] provide formulas based on different approaches. The former, based on EN 1992-1-1 [24], presents a modified formula that accounts for the presence of fibers by means of their aspect ratio. Conversely, MC 2010 provides a formula based on the mechanical properties of FRC, which is assumed as a performance-based material. Several studies on the correlation between the crack width and the spacing with fiber content and fiber aspect ratio can be found in $[3,27-30]$.

However, there are not significant studies reported in scientific literature regarding the influence of sustained loads on the crack width of RC/FRC members. In this perspective, the present study aims to shed some new light on the field. In general, the evolution of crack width in the long term is strongly related to several factors, such as the variability of concrete properties and the possible changes in water content, temperature and loading level. Usually, design guidelines provide simplified methods to take into account the time-dependent effects on crack width [2,24]; the simplified approaches available are in good accordance with experimental results obtained from plain concrete beams but, in FRC beams, their effectiveness should be further assessed. In fact, the presence of fibers in the concrete matrix may affect the strain distribution during long term loading. Only few studies were focused on creep effects [31-36], and analytical models are not yet fully developed [3,5].

This paper presents the final outcomes of an experimental campaign started in 2008, whose early results are already discussed in [5] and [23], regarding the control beams and those conditioned during the first 17 months. The study presents the results of an experimental campaign focusing on cracking and the long-term behavior of FRC beams conventionally reinforced with longitudinal and transversal steel reinforcement; some durability issues (chloride penetration and carbonation depth) are also discussed. The experimental program concerns full-scale FRC beams exposed up to 72 months to the environment with a sustained load of $50 \mathrm{kN}$, corresponding to service load. The residual bearing capacity of the beams was finally measured through a four point bending test. The experimental measurements concern the crack width and any flexural displacements during the test.

\section{Experimental Program}

The entire experimental campaign started in 2008 at the University of Salento (Lecce, Italy). Thirteen beams were cast with different fiber types and contents. Three control beams (Set \#1, L label is for laboratory) were tested under a four point bending loading after 12 months of curing. The remaining beams (_E label) were moved outside and placed into two loading steel frames located in an industrial area, which was $500 \mathrm{~m}$ from the sea; these beams were exposed to natural weathering with a sustained service load of $50 \mathrm{kN}$. In particular, five beams (Set \#2) were exposed for about 17 months (_17 label) while the remaining five beams (Set \#3) were exposed for about 72 months (_72 label). Each group (Set \#2 and \#3) includes a single plain concrete beam (_PC label), two steel FRC beams (_ST label) and two polyester FRC beams (_POL label). 
The beams of Set \#2 and \#3 were piled up in a steel frame in order to counterbalance the self-weight of each beam, and were then subjected to a four point bending scheme. A load of $50 \mathrm{kN}$ was applied by means of screw jacks, and measured by two loading cells. During the exposure, the crack pattern evolution (namely the position, length and width of cracks) was regularly checked on each beam. The crack width was measured by means of a handheld digital microscope along each beam, at the bottom of their tension side.

After exposure, all of the beams were tested in the laboratory under the same four point bending scheme adopted in the loading frames for sustained loads. During all of the laboratory tests, the deflections were monitored and recorded by using three resistive $50 \mathrm{~mm}$ displacement transducers. The crack pattern of each beam was accurately detected and registered at the five loading steps.

\subsection{Materials Properties}

Three different concrete mixes were prepared: A plain concrete (PC) control mix, two fiber-reinforced concrete (FRC) mixes, embedding respectively steel fibers (ST) with a $0.6 \%$ volume fraction, and polyester fibers (POL), with a $0.9 \%$ volume fraction. A description of each component material is presented in the following.

The concrete mix includes the Portland cement type CEM A-LL 32,5 R, which is based on limestone Portland type II with a high initial strength.

Steel and polyester short fibers were used in the concrete mixes. Hooked steel fibers having a length of $30 \mathrm{~mm}$, a diameter of $0.6 \mathrm{~mm}$ and an aspect ratio (L/D) of 50, were adopted. The quality of the steel fibers meets the requirements of the UNI 11037 [37]. Polyester fibers had a length of $30 \mathrm{~mm}$, a diameter of $0.45 \mathrm{~mm}$ and an aspect ratio (L/D) of 66. Steel fibers had tensile strength and elastic modulus as equal to $1150 \mathrm{MPa}$ and $210 \mathrm{GPa}$, respectively, while polyester fibers had a strength of $600 \mathrm{MPa}$ and an elastic modulus of $11.3 \mathrm{GPa}$.

Longitudinal and transversal steel reinforcement was provided in the form of bars ( $\Phi 14 \mathrm{~mm})$ and stirrups $(\Phi 8 \mathrm{~mm})$, having a yield strength of $520 \mathrm{MPa}$ and $567 \mathrm{MPa}$, and a tensile strength of $614 \mathrm{MPa}$ and $600 \mathrm{MPa}$, respectively.

The concrete matrix was made by using $300 \mathrm{~kg} / \mathrm{m}^{3}$ of cement type $32.5 \mathrm{R}$ II-A/LL, a water/cement ratio of 0.65 and a maximum aggregate size of $12 \mathrm{~mm}$ (see Table 1 for the mix design). The FRC workability was measured with a slump test according to EN 206-1 [38] and the class resulted S5. The maximum aggregate size was chosen in order to allow a uniform and efficient distribution of fibers within the mold. Four cubic specimens $(150 \times 150 \times 150 \mathrm{~mm})$ for each concrete mix $(\mathrm{PC}, \mathrm{ST}$ and POL) were tested under uniaxial compression for quality control. Table 2 reports the cubic compressive strengths (average value from four samples $150 \times 150 \times 150 \mathrm{~mm}$ ) after 28 days from casting, and the corresponding elastic moduli obtained according to ISO 6784 [39]. Tests on notched beams subjected to a three-point load were also carried out according to EN 14651 [40]. The main experimental results are reported in Table 2; it can be noticed that the steel fibers were more effective than polyester fibers in terms of toughness, as shown by parameters $\mathrm{f}_{\mathrm{R} 1}$ as defined by EN 14651 [40].

Table 1. Mix design.

\begin{tabular}{cccc}
\hline Concrete Mix Components & ST & POL & PC \\
\hline CEM 32.5 R II-A/LL $\left(\mathrm{kg} / \mathrm{m}^{3}\right)$ & 300 & 300 & 300 \\
Superplasticizer CRTV-L $\left(\mathrm{kg} / \mathrm{m}^{3}\right)$ & 1.59 & 2.5 & 1.77 \\
Sand (0-4) $\left(\mathrm{kg} / \mathrm{m}^{3}\right)$ & 1028 & 1023 & 1037 \\
Gravel $(4-10)\left(\mathrm{kg} / \mathrm{m}^{3}\right)$ & 704 & 701 & 710 \\
Water/Cement ratio & 0.65 & 0.65 & 0.65 \\
\hline
\end{tabular}


Table 2. Cubic compressive strength.

\begin{tabular}{ccccc}
\hline Specimen & $\begin{array}{c}\text { Average Strength * } \\
\text { (MPa) }\end{array}$ & COV (\%) & $\begin{array}{c}\text { Elastic Modulus } \\
(\mathbf{G P a})\end{array}$ & $\mathbf{f}_{\mathbf{R} \mathbf{~}}(\mathbf{M P a})$ \\
\hline PC & 25.80 & 4.1 & 27.712 & - \\
ST & 21.40 & 8.2 & 25.874 & 0.88 \\
POL & 23.20 & 8.4 & 26.748 & 0.40 \\
\hline
\end{tabular}

${ }^{*}$ Cubic specimens.

\subsection{Beam Design and Geometry}

Reinforced concrete beams with a length of $3000 \mathrm{~mm}$ and a cross section of $250 \times 250 \mathrm{~mm}$ were designed according to EC-2 [24]. The external supports were spaced $2800 \mathrm{~mm}$ apart, and the two loading points were set at a distance of $900 \mathrm{~mm}$ from each other, according to a four point bending scheme. The amount of steel reinforcement was chosen in order to assure a ductile bending failure of the beam, with a yield of the rebars and the concrete crushing at failure. Hence, the beams were reinforced with $2 \Phi 14$ (upper) and $3 \Phi 14$ (lower) rebars, with a concrete cover of $30 \mathrm{~mm}$. Web reinforcement (vertical stirrups) was designed to prevent undesired shear failure; stirrups were $\Phi 8 \mathrm{~mm}$ with a spacing of $140 \mathrm{~mm}$ in the central part of the beam, while they were $70 \mathrm{~mm}$ spaced close to the supports. More details about the beams and the steel reinforcement are reported in [5].

\subsection{Flexural Tests of Beams}

\subsubsection{Test Set-Up}

The Figure 1 shows the stacking of the beams under sustained loading, by also reproducing the cracking patterns after the exposure period outdoors. After long term exposure the beams were subjected to a four-point bending test in the laboratory. The experimental set-up and the loading procedure are described in the following. The load was applied by means of a 30-ton hydraulic jack, and was measured by a $300 \mathrm{kN}$ load cell, connected to an electronic data logger able to record all of the monitored data channels. Three linear variable displacement transformers (LVDT) were placed at mid-span and at the quarters (see Figure 2a). In order to measure deformations during the test, electrical strain gauges were applied on both concrete and longitudinal steel bars. Three strain gauges were used for the measurement of maximum concrete strains (at the compressive side of the beams at the mid-span section). Figure $2 b$ shows the back view of the steel reinforcement and of the instrumented beam, and a photo of the beam during the test.

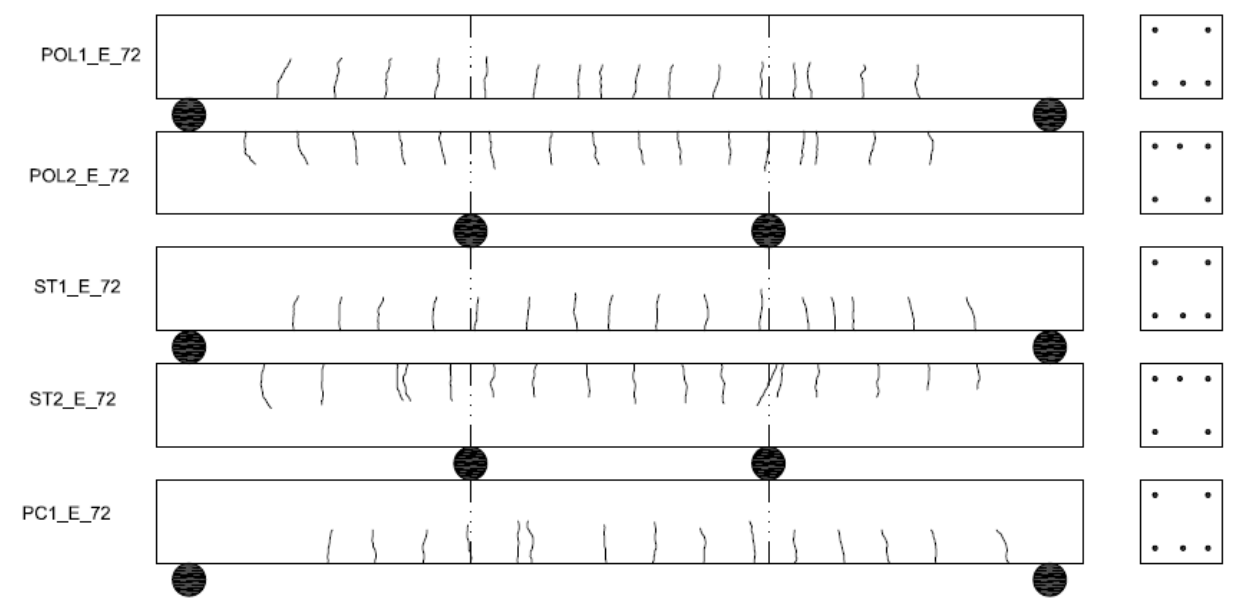

Figure 1. Sustained loading scheme used in the frames. 

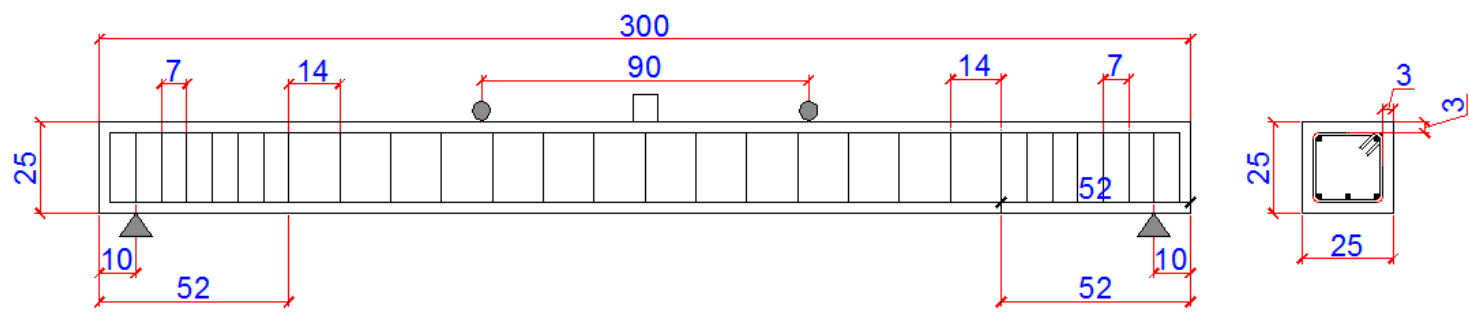

(a)

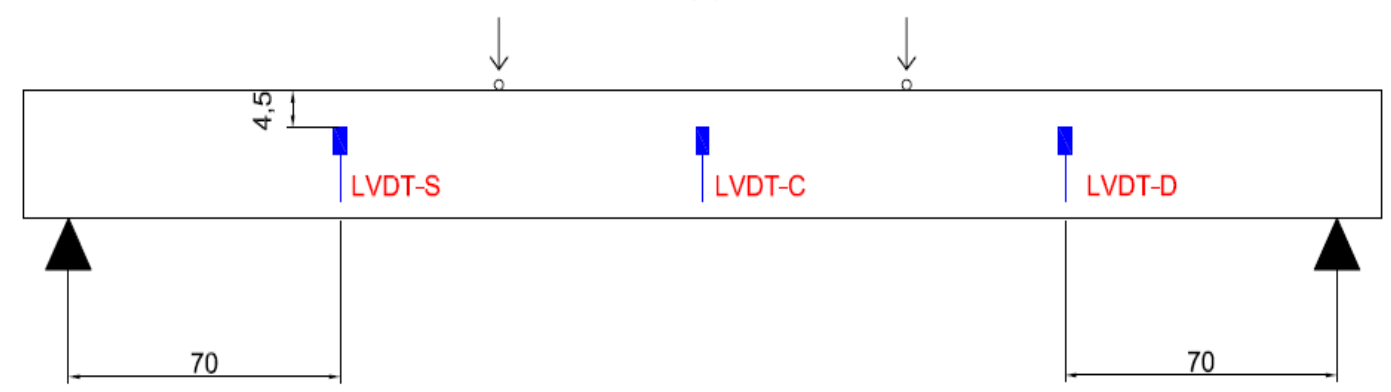

(b)

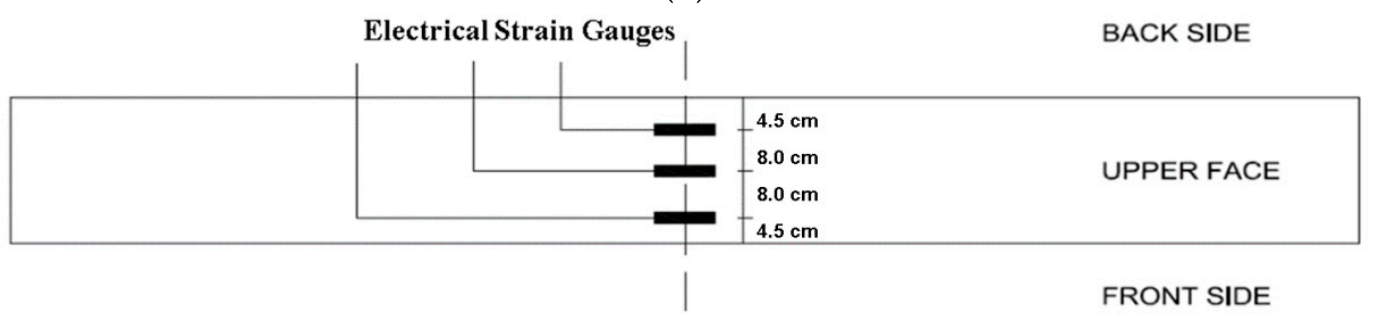

(c)

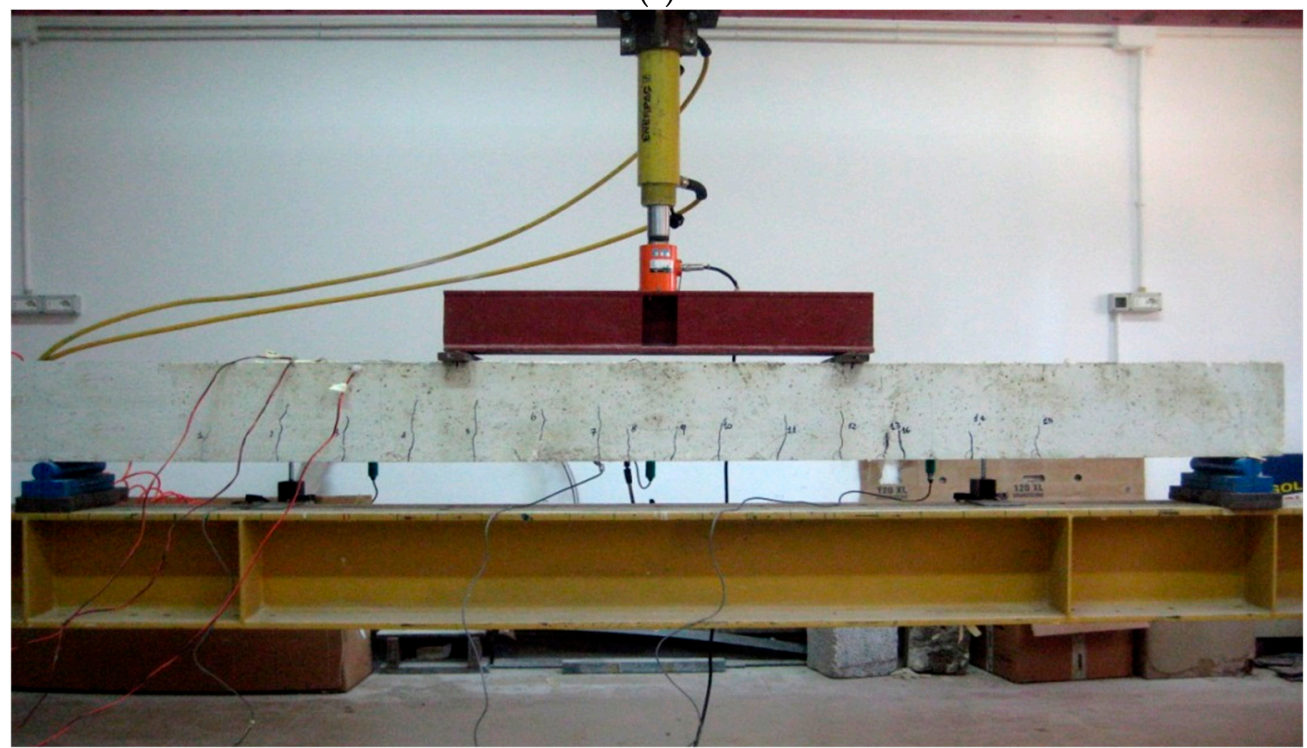

(d)

Figure 2. Reinforcement geometry (a); Back (b) and top (c) views of the instrumented beam-(measures in $\mathrm{cm}$ ); final bending test (d).

\subsubsection{Test Procedure}

Before starting the final bending test, the crack pattern developed during the exposure time was carefully detected and referred to as step 0 or the residual condition. The tip of every single crack was 
marked before starting the final test in order to verify its final development. Starting from the initial conditions (Step 0), the beams were loaded monotonically until failure.

Even if experimental measurements were continuously recorded, five intermediate steps $(20 \mathrm{kN}$; $30 \mathrm{kN} ; 50 \mathrm{kN} ; 80 \mathrm{kN} ; 100 \mathrm{kN}$ ) were taken as a reference for crack width, length and spacing. In the beams that did not reach the load of $100 \mathrm{kN}$ (mainly the PC beams), namely the nominal ultimate load value predicted at the design stage, the last measurements were taken at a mid-span displacement of $20 \mathrm{~mm}$ (for the sake of comparison). At each of these five steps, the crack width and position as well as the complete development of the crack pattern were recorded. The crack widths were measured by using an electronic lens with a magnification factor of up to 200× (as during exposure), supported by an image processing software.

\section{Experimental Results and Discussion}

Experimental results on the beams exposed for 17 months clearly show that the presence of fibers helps in reducing the crack width and contributes to an earlier stabilization (after about ten months of exposure for FRC) of crack development $[5,23]$.

\subsection{Long-Term Behavior}

\subsubsection{Mechanical Behavior}

As experienced also for the beams tested in the first part of the program (Set \#2), during the final loading stage the beams of Set \#3 collapsed by concrete crushing after the yielding of the tensile bars (as expected from the design process). At failure, the PC beams showed the most extensive concrete damage, with concrete spalling at the upper compressive side. The flexural behavior of the reference beams tested under short-term conditions was very similar, showing a typical pseudo bi-linear curve. As also was found on the beams of Set \#1 and \#2, the influence of the fibers was almost negligible in terms of flexural strength, according to available literature [41-44]. As for Set \#1 and \#2, also in Set \#3 a slight increment of yielding loads (4-8\%) was registered in the FRC beams, due to the tensile contribution of fiber reinforcement.

For both Set \#2 and \#3, the flexural stiffness of the FRC beams was greater than that of the PC beams up to the service loads, while for Set \#1 they were comparable (Table 3). It should also be noticed that, at the end of the test (17 months for_E17 and 72 months for_E72 beams), exposed beams of Sets $\# 2$ and \#3 had lower stiffness than the corresponding laboratory beams (up to $50 \mathrm{kN}$ ) and the stiffness reduction was more evident in the PC beams (Figure 3).

Table 3. Analysis of mechanical performance for the 72-month exposed beams in the four-point bending test.

\begin{tabular}{|c|c|c|c|c|c|c|c|c|c|c|}
\hline \multirow{2}{*}{$\begin{array}{l}\text { Beam } \\
\text { ID Tag }\end{array}$} & \multicolumn{2}{|c|}{ Stiffness $[\mathrm{kN} / \mathrm{m}]$} & \multicolumn{5}{|c|}{ Midspan Deflection [mm] } & \multirow{2}{*}{$\begin{array}{l}\text { Ult. Load } \\
(\mathrm{kN})\end{array}$} & \multirow{2}{*}{$\begin{array}{l}\text { Steel Yield. } \\
\text { Load (kN) }\end{array}$} & \multirow{2}{*}{ Ductility } \\
\hline & $0-50 \mathrm{kN}$ & $\Delta^{*}$ & $20 \mathrm{kN}$ & $30 \mathrm{kN}$ & $50 \mathrm{kN}$ & $80 \mathrm{kN}$ & Failure & & & \\
\hline PC_L & 7027 & - & 1.94 & 3.99 & 7.10 & 12.39 & 45.42 & 107.62 & 84.24 & 3.51 \\
\hline POL_L & 7246 & $3 \%$ & 1.42 & 2.74 & 6.90 & 11.55 & 41.38 & 105.52 & 88.03 & 3.14 \\
\hline ST_L & 7849 & $12 \%$ & 1.54 & 3.06 & 6.37 & 11.67 & 53.36 & 107.12 & 91.43 & 3.78 \\
\hline PC1_E_17 & 6303 & - & 3.53 & 5.08 & 7.93 & 11.47 & 46.10 & 104.42 & 88.33 & 3.47 \\
\hline POL1_E_17 & 8865 & $41 \%$ & 2.03 & 3.35 & 5.64 & 9.55 & 44.61 & 105.82 & 87.84 & 4.01 \\
\hline POL2_E_17 & 9016 & $43 \%$ & 2.20 & 3.36 & 5.54 & 8.88 & 37.92 & 110.92 & 90.23 & 3.68 \\
\hline ST1_E_17 & 8956 & $42 \%$ & 2.27 & 3.40 & 5.58 & 8.63 & 35.82 & 110.42 & 91.93 & 3.46 \\
\hline ST2_E_17 & 9891 & $57 \%$ & 1.56 & 2.80 & 5.05 & 8.26 & 38.16 & 117.41 & 92.93 & 3.93 \\
\hline PC_E_72 & 6312 & - & 3.03 & 4.80 & 7.92 & 11.86 & 49.50 & 108.12 & 92.5 & 3.54 \\
\hline POL1_E_72 & 7365 & $17 \%$ & 2.79 & 4.16 & 6.78 & 10.97 & 56.47 & 104.72 & 94.93 & 4.03 \\
\hline POL2_E_72 & 6554 & $4 \%$ & 3.20 & 4.69 & 7.62 & 12.00 & 49.75 & 104.42 & 94.13 & 3.25 \\
\hline ST1_E_72 & 7653 & $21 \%$ & 2.72 & 4.04 & 6.53 & 10.13 & 65.70 & 107.92 & 95.23 & 5.39 \\
\hline ST2_E_72 & 7210 & $14 \%$ & 2.98 & 4.37 & 6.93 & 10.80 & 46.99 & 110.42 & 98.73 & 4.33 \\
\hline
\end{tabular}




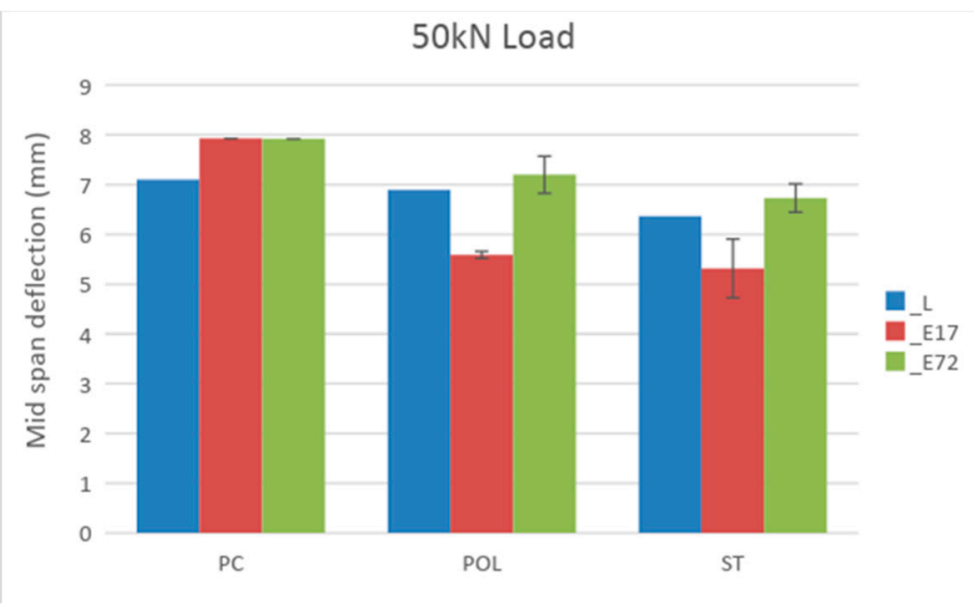

Figure 3. Mid-span deflection values under a service load of $50 \mathrm{kN}$ at the end of the test (17 months for _E17 and 72 months for_E72 beams).

Figure 4 shows the load vs. mid-span displacement curves for all of the beams of Set \#3, tested after 72 months of environmental and mechanical aging; the higher ductility of these FRC beams with respect to the plain concrete beam can be noticed; a ductility index is here assumed as the ratio between the ultimate and yielding deflection. However, the increase in ductility was limited for beams containing polyester fibers, while it was remarkable (up to $20 \%$ ) for beams with steel fibers. The measured values of ductility are 3.50, 3.62 and 4.18 for PC, POL and ST beams, respectively (average values for FRC beams).

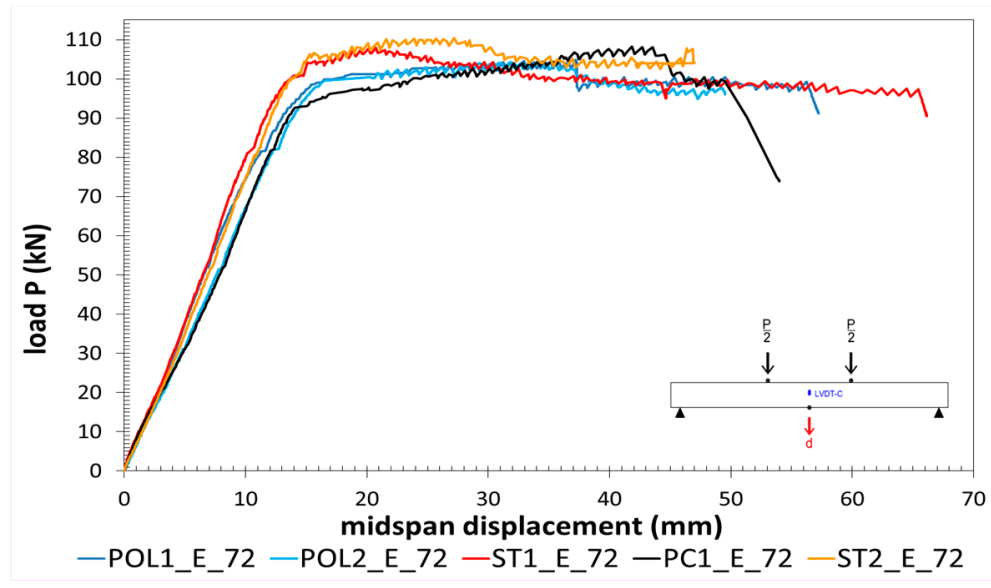

Figure 4. Load vs. mid-span deflection curves for beams aged for 72 months.

\subsubsection{Cracking Behavior}

The cracking behavior of beams of Set \#2 (exposed for 17 months) and of Set \#3 (exposed for 72 months) is presented and discussed in this section. The discussion mainly concerns the crack width, since the crack distance was governed by stirrup distance. The measurements of the crack width during the sustained load of $50 \mathrm{kN}$ (Set \#2 and \#3) showed that a smaller crack width was observed in the FRC beams (50-60\% with respect to PC beam). Unfortunately, the last continuative measurement of crack width on the beams of Set \#3 was taken after 23 months of exposure (due to the impossibility to gain access in the area at the time), when the average values of the crack width were equal to 0.26 , 0.17 and $0.14 \mathrm{~mm}$ for PC, ST and POL beams, respectively.

Figure 5 shows a comparison between the beams of Set \#2 and \#3 in terms of crack opening in the constant moment region versus load, during the final loading test in the laboratory (after exposure); 
once again, it can be noticed that these FRC beams show lower values of crack width than the PC beam, especially in the last stages of loading. It can be also noticed that, at the service load (50-60 kN), polyester fibers have a similar effect to steel fibers.

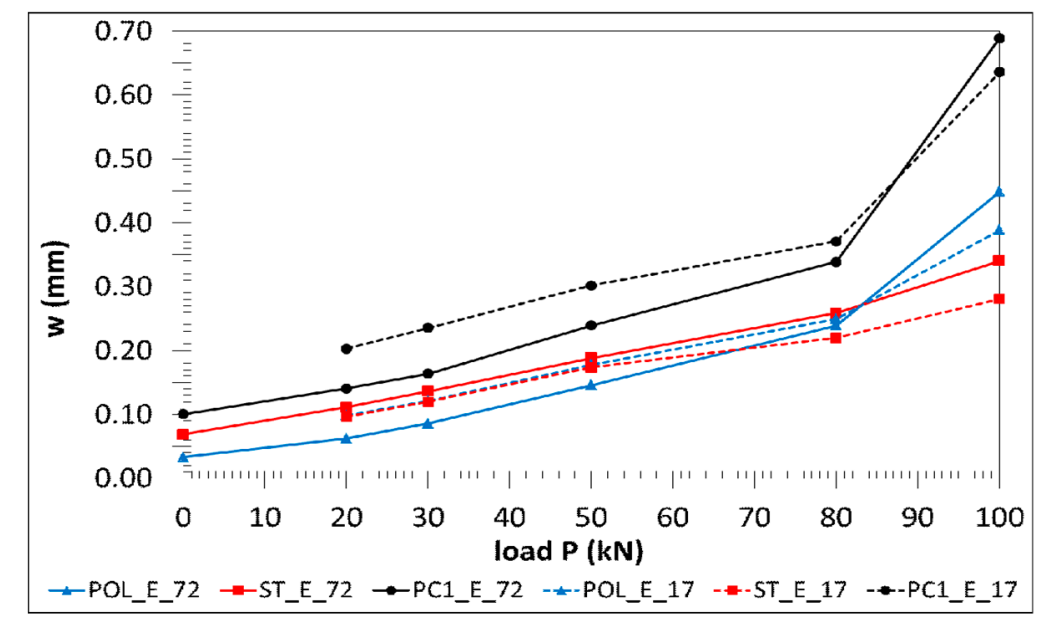

Figure 5. Mean crack width in the constant moment region—Set \#2 and \#3.

Other valuable considerations arise when taking into account the crack length and the crack width measured in the constant moment zone for all of the exposed beams of Set \#3 under the sustained load of $50 \mathrm{kN}$. In particular, in the constant moment region, the total crack width, calculated as the sum of the crack widths in the constant moment zone of each beam, is 30\% smaller in FRC beams than that measured in the PC beams. The comparison between Set \#3 and Set \#2, in terms of mean crack width in the constant moment region, did not provide substantial differences.

Figure 6 also reports relevant results recorded in the field, in terms of crack width versus time. The mean crack was computed as the average value between the maximum crack openings in the constant moment region. It is clear, from the plots, that those concrete beams incorporating short fibers show a cracking behavior which is mitigated in terms of width. Moreover, the stabilization of the crack width is reached earlier for the FRC beams with respect to the ordinary RC beams.

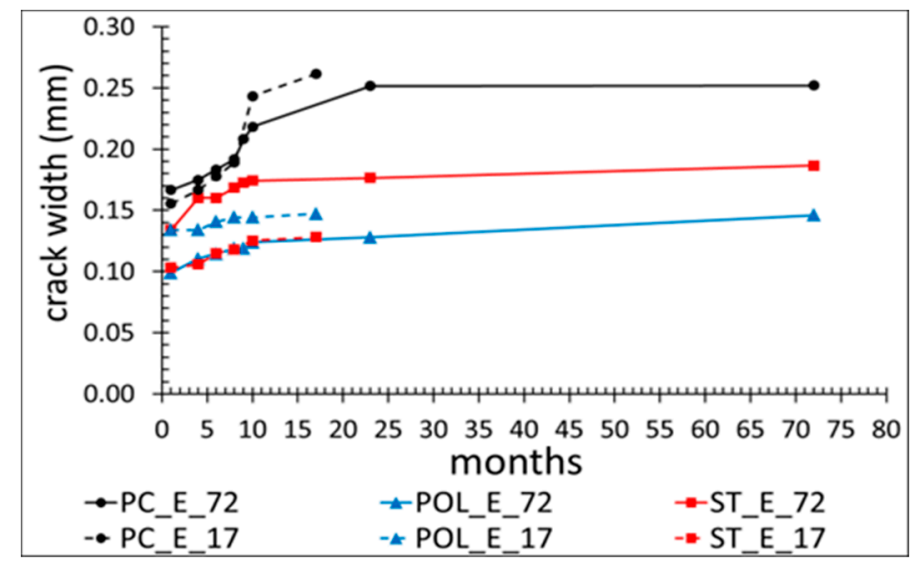

Figure 6. Mean crack width over the constant moment zone vs. time.

Figure 7 shows that, in cracked sections, the PC beams had the higher value of the maximum carbonation depth $(49.1 \mathrm{~mm})$ as compared to the FRC beams $(45.1 / 34 \mathrm{~mm}$ for ST1/ST2 and 37.4/36.2 for POL1/POL2); therefore, the beneficial effect of short fibers in the concrete mix is confirmed [23]. 


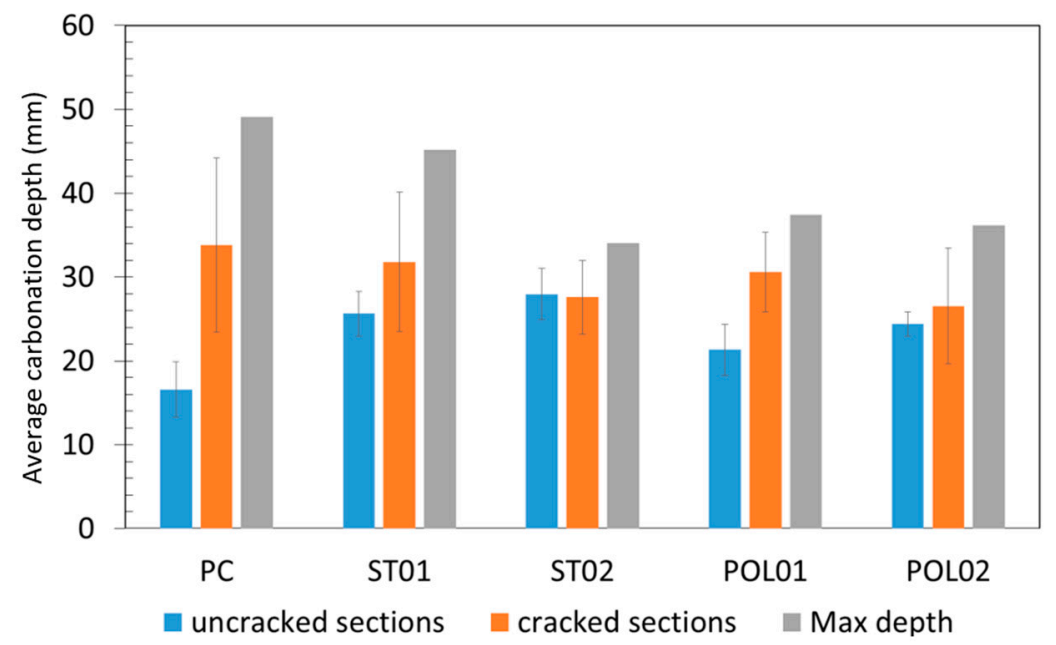

Figure 7. Carbonation depth and standard deviation for 72-month exposed beams.

\subsubsection{Durability Tests}

After carrying out the mechanical tests, the beams were cut both along the cross and longitudinal directions in order to perform durability tests. Firstly, ion chloride penetration was checked in cross sections by means of a colorimetric test based on a sprayed solution of silver nitrate $\left(\mathrm{AgNO}_{3}\right)$. No reaction displaying a violet color was assessed by infrared light, not even after alkalizing the surfaces. Therefore, according to Meira et al. [44], it is likely that the chloride content is lower than $0.012 \%$ of the concrete weight; for this reason, it can be considered negligible.

Carbonation depth was checked at both cracked and uncracked sections, leading to interesting, and somehow apparently controversial, results. Table 4 reports the mean carbonation depth values obtained from measurements taken on both sides of the longitudinal sections for each single beam exposed for 72 months. The mentioned mean values refer to the measurements taken respectively at all cracked sections along the constant moment zone and in 12 points of the uncracked area. FRC beams showed lower crack widths and slightly lower carbonation depths in cracked sections than the PC beams. However, in uncracked sections the carbonation depth in the FRC beams is slightly greater than in those PC beams; this is probably due to the increased porosity of FRCs, which show a higher content of entrapped air in the mold than the PC mix [45]. The increased content of entrapped air is a consequence of the reduced workability of FRC, and is considered the main cause of the slightly reduced compressive strength of FRC (Table 2). This clearly evidences that a proper mix design becomes a major issue in FRC in order to avoid reduced workability and a consequent increase of porosity.

Table 4. Carbonation depths and standard deviation for 72-month exposed beams.

\begin{tabular}{cccccc}
\hline & \multicolumn{2}{c}{ Uncracked Sections } & \multicolumn{3}{c}{ Cracked Sections } \\
\hline $\begin{array}{c}\text { Beam ID } \\
\text { Tag }\end{array}$ & $\begin{array}{c}\text { Carbonation } \\
\text { Depth } \\
(\mathbf{m m})\end{array}$ & $\begin{array}{c}\text { Standard } \\
\text { Deviation }\end{array}$ & $\begin{array}{c}\text { Carbonation } \\
\text { Depth } \\
(\mathbf{m m})\end{array}$ & $\begin{array}{c}\text { Standard } \\
\text { Deviation }\end{array}$ & $\begin{array}{c}\text { Maximum } \\
\text { Carbonation } \\
\text { Depth }\end{array}$ \\
\hline PC_E_72 & 16.59 & 3.30 & 33.82 & 10.41 & 49.13 \\
ST1_E_72 & 25.63 & 2.68 & 31.81 & 8.33 & 45.16 \\
ST2_E_72 & 27.97 & 3.04 & 27.59 & 4.41 & 34.02 \\
POL1_E_72 & 21.31 & 3.06 & 30.61 & 4.77 & 37.44 \\
POL2_E_72 & 24.41 & 1.44 & 26.55 & 6.93 & 36.18 \\
\hline
\end{tabular}

The carbonation depth $D$ (measured in $\mathrm{mm}$ ) in uncracked concrete sections can be determined by means of the well-known Tuutti's formula $D=K \times t^{0.5}$, where $K$ is the carbonation coefficient 
and $t$ is the time in years [46]. Taking into account the exposure time and the carbonation depths reported in Table 4, the $K$ coefficients for each exposed beam can be obtained, as reported in Table 5; results confirm the observation reported in [23]: Carbonation agents penetrate faster into cracks than in uncracked concrete, and carbonation coefficients are lower for FRC compared to PC. It can be noticed that the values of coefficients $K$ are similar between beams with same mix exposed, respectively for 17 and 72 months (except for PC_E_72, which had a K value in cracked sections 30\% lower than that of PC_E_17). Figure 7 shows the average values of the carbonation depth, as measured in the beams of Set \#3 after 72 months of exposure.

Table 5. Carbonation coefficients in exposed beams: 17 vs. 72 months.

\begin{tabular}{|c|c|c|c|c|c|}
\hline \multirow[b]{2}{*}{$\begin{array}{l}\text { Beam ID } \\
\text { Tag }\end{array}$} & \multicolumn{2}{|c|}{$\mathrm{K}\left(\mathrm{mm} /\right.$ year $\left.^{0.5}\right)$} & \multirow[b]{2}{*}{$\begin{array}{l}\text { Beam ID } \\
\text { Tag }\end{array}$} & \multicolumn{2}{|c|}{$\mathrm{K}\left(\mathrm{mm} /\right.$ year $\left.^{0.5}\right)$} \\
\hline & $\begin{array}{c}\text { Uncracked } \\
\text { Sections }\end{array}$ & $\begin{array}{l}\text { Cracked } \\
\text { Sections }\end{array}$ & & $\begin{array}{c}\text { Uncracked } \\
\text { Sections }\end{array}$ & $\begin{array}{l}\text { Cracked } \\
\text { Sections }\end{array}$ \\
\hline PC_E_72 & 6.77 & 13.30 & PC_E_17 & 8.07 & 19.38 \\
\hline ST1_E_72 & 10.46 & 12.99 & ST1_E_17 & 8.46 & 12.69 \\
\hline ST2_E_72 & 11.42 & 11.26 & ST2_E_17 & 8.18 & 13.44 \\
\hline POL1_E_72 & 8.70 & 12.96 & POL1_E_17 & 9.11 & 12.49 \\
\hline POL2_E_72 & 9.97 & 11.21 & POL2_E_17 & 9.05 & 12.58 \\
\hline
\end{tabular}

The application of Tuutti's formula provides the predictions of the time to the start of corrosion (in months) for the tested beams (Table 6); however, it should be underlined that the load level applied in the long-term tests $(50 \mathrm{kN})$ was higher than the quasi-permanent load assumed by EC-2 [24].

Table 6. Estimated time for the start of corrosion in exposed beams (17 and 72 months).

\begin{tabular}{cccc}
\hline Beam ID Tag & T (Months) & Beam ID Tag & T (Months) \\
\hline PC_E_72 & 61.0 & PC_E_17 & 28.8 \\
ST1_E_72 & 64.0 & ST1_E_17 & 67.1 \\
ST2_E_72 & 85.2 & ST2_E_17 & 60.0 \\
POL1_E_72 & 64.3 & POL1_E_17 & 69.2 \\
POL2_E_72 & 85.9 & POL2_E_17 & 68.2 \\
\hline
\end{tabular}

\section{Conclusions}

In the present paper, the results of an extensive experimental campaign with the aim of investigating the beneficial effects of short (steel and polyester) fibers in FRC beams under sustained loads are presented and discussed with special attention to long-term behavior and durability. Fibers were used as additional reinforcement to rebars present in all of the beams, and designed according to Eurocode 2 .

Ten Reinforced Concrete (RC) beams were monitored for several months during exposure to natural agents under sustained (service) load. In addition, three reference RC/FRC beams (made of the same materials) were tested 28 days after casting without any environmental exposure (Set \#1).

After long-term loading and exposure (17 months for Set \#2 and 72 months for Set \#3), all of the beams were unloaded and tested in the laboratory under monotonic conditions up to failure.

Experimental results confirm that fiber reinforcement helps in reducing crack width and in increasing the flexural stiffness of the FRC beams. In fact, long term loading provokes an increase of deformations that corresponds to a stiffness loss which was particularly evident in PC beams. The FRC beams with steel fibers showed the highest flexural strength.

The use of FRC (in addition to conventional reinforcement) allows for a reduction of the crack width of up to $50 \%$. In particular, up to the service load (about $50-60 \mathrm{kN}$ ), polyester FRC beams have shown lower values of mean crack width, compared to steel FRC beams. However, FRC beams with steel fibers showed the maximum flexural strength (due to the highest fracture energy of FRC). 
Furthermore, FRC led to an enhanced ductility in structural members (especially in beams with steel fibers) and to smaller mid-span deflections.

The beneficial effect of fibers has been studied also in terms of durability. In fact, FRC beams have shown a lower crack width and, therefore, a lower carbonation depth at the cracked sections (than do the PC beams). However, in uncracked sections the carbonation depth of the FRC beams was slightly higher than that in the PC beams, probably due to the higher porosity of the matrix provoked by the reduced workability of FRC.

Finally, the experimental results of the long-term bending tests clearly show the beneficial effects from FRC; such properties make FRC a suitable material for improving the service life performance of reinforced concrete structures.

Author Contributions: Conceptualization, G.P., M.A.A. and F.M.; methodology, G.P., M.A.A., F.M. and E.V.; investigation, E.V., L.C., F.M.; data curation, E.V. and L.C.; writing-review and editing, F.M., E.V., L.C.; supervision, G.P. and M.A.A.; project administration G.P. and M.A.A.

Funding: This research received no external funding.

Acknowledgments: The authors would acknowledge the support of Italcementi (Heidelbergcement Group) who strongly contributed to the development of this research by providing materials and support in preparing samples and materials testing.

Conflicts of Interest: The authors declare no conflict of interest.

\section{References}

1. Di Prisco, M.; Plizzari, G.; Vandewalle, L.; Prisco, M. Fibre reinforced concrete: new design perspectives. Mater. Struct. 2009, 42, 1261-1281. [CrossRef]

2. International Federation for Structural Concrete. Model Code First Complete Draft; International Federation for Structural Concrete: London, UK, 2010; p. 312. ISBN 978-2-88394-096-3.

3. Tan, K.H.; Paramasivam, P.; Tan, K.C. Cracking characteristics of reinforced steel fibre concrete beams under short and long-term loadings. Adv. Cem. Based Mater. 1995, 2, 127-137.

4. Altoubat, S.A.; Lange, D.A. A new look at tensile creep of fibre reinforced concrete. ACI Spec. Publ. Fiber Reinforced Concr. 2003, 216, 143-160.

5. Vasanelli, E.; Micelli, F.; Aiello, M.A.; Plizzari, G. Crack width prediction of FRC beams in short and long term bending condition. Mater. Struct. 2014, 47,39-54.

6. Ferreira, L.E.T.; Hanai, J.B.; Bittencourt, T.N. Computational evaluation of flexural toughness of FRC and fracture properties of plain concrete. Mater. Struct. 2008, 41, 391-405. [CrossRef]

7. Cadoni, E.; Meda, A.; Plizzari, G.A. Tensile behaviour of FRC under high strain-rate. Mater. Struct. 2009, 42, 1283-1294.

8. Carmona Malatesta, S.; Aguado de Cea, A.; Molins Borrell, C. Generalization of the Barcelona test for the toughness control of FRC. Mater. Struct. 2012, 45, 1053-1069.

9. Candido, L.; Micelli, F. Seismic behaviour of regular reinforced concrete plane frames with fiber reinforced concrete in joints. Bull. Earth Eng. 2018, 16, 4107-4132.

10. Yuan, F.; Pan, J.; Xu, Z.; Leung, C.K.Y. A comparison of engineered cementitious composites versus normal concrete in beam-column joints under reversed cyclic loading. Mater. Struct. 2013, 46, 145-159. [CrossRef]

11. Bayasi, Z.; Gebman, M. Reduction of lateral reinforcement in seismic beam-column connection via application of steel fibres. ACI Struct. J. 2002, 99, 772-780.

12. Filiatrault, A.; Pineau, S.; Houde, J. Seismic behavior of steel-fibre reinforced concrete interior beam-column joints. ACI Struct. J. 1995, 92, 543-552.

13. Henager, C.H. Steel fibrous-ductile concrete joint for seismic-resistant structures. Spec. Publ. 1977, 53, 371-386.

14. Jiuru, T.; Chaobin, H.; Kaijian, Y.; Yongcheng, Y. Seismic behavior and shear strength of framed joint using steel-fibre reinforced concrete. J. Struct. Eng. ASCE 1992, 118, 341-358. [CrossRef]

15. Pantelides, C.P.; Garfield, T.T.; Richins, W.D.; Larson, T.K.; Blakeley, J.E. Reinforced concrete and fiber reinforced concrete panels subjected to blast detonations and post-blast static tests. Eng. Struct. 2014, 76, 24-33. [CrossRef] 
16. Foglar, M.; Kovar, M. Conclusions from experimental testing of blast resistance of FRC and RC bridge decks. Int. J. Impact. Eng. 2013, 59, 18-28. [CrossRef]

17. Parra-Montesinos, G.J. High-performance fibre-reinforced cement composites: An alternative for seismic design of structures. ACI Struct. J. 2005, 102, 668.

18. Mishra, D.K.; Li, V.C. Performance of a ductile plastic hinge design with an engineered cementitious composite. UMCEE Rep. 1995, 95-06, 9527701.

19. Minelli, F. Plain and Fiber Reinforced Concrete Beams Under Shear Loading: Structural Behaviour and Design Aspects. Ph.D. Thesis, University of Brescia, Brescia, Italy, 2005.

20. Tiberti, G.; Minelli, F.; Plizzari, G.A.; Vecchio, F.J. Influence of concrete strength on crack development in SFRC members. Cem. Concr. Compos. 2014, 45, 176-185. [CrossRef]

21. Borosnyói, A.; Balázs, L. Models for flexural cracking in concrete: The state of the art. J. Struct. Concr. 2005, 6, 52-62. [CrossRef]

22. Chiaia, B.; Fantilli, A.P.; Vallini, P. Evaluation of crack width in FRC structures and application to tunnel linings. Mater. Struct. 2009, 42, 339-351. [CrossRef]

23. Vasanelli, E.; Micelli, F.; Aiello, M.A.; Plizzari, G. Long term behavior of FRC flexural beams under sustained load. Eng. Struct. 2013, 56, 1858-1867. [CrossRef]

24. European Committee for Standardization. EN 1992-1-1. Eurocode2 1991 Design of Concrete Structures-Part 1: General Rules and Rules for Buildings; European Committee for Standardization: Bruxelles, Belgium, 1992; p. 209.

25. ACI Committee 224. Control of cracking of concrete structures. Am. Conc. I 2001, 224R-01, 1-49.

26. RILEM TC 162-TDF. Test and design methods for steel fibre reinforced concrete- $\sigma-\varepsilon$ design method-Final recommendation. Mater. Struct. 2003, 36, 560-567. [CrossRef]

27. Vandewalle, L. Cracking behaviour of concrete beams reinforced with a combination of ordinary reinforcement and steel fibres. Mater. Struct. 2000, 33, 164-170. [CrossRef]

28. Oh, B.H. Flexural analysis of reinforced concrete beams containing steel fibres. J Struct. Eng. ASCE 1992, 118, 2821-2836. [CrossRef]

29. Balazs, G.L.; Kovacs, I. Effect of steel fibres on the cracking behaviour of RC members. In Proceedings of the 6th RILEM Symposium on Fibre-Reinforced Concretes (BEFIB 2004), Varenna, Italy, 20-22 September 2004; pp. 20-22.

30. Leutbecher, T.; Fehling, E. Tensile behaviour of ultra-high-performance concrete reinforced with reinforcing bars and fibres: Minimizing fibre content. ACI Struct. J. 2012, 109, 253-263.

31. Bissonnette, B.; Pigeon, M. Tensile creep at early ages of ordinary, silica fume and fibre reinforced concretes. Cem. Concr. Res. 1995, 25, 1075-1085. [CrossRef]

32. Barragán, B.E.; Zerbino, R.L. Creep behaviour of cracked steel fibre reinforced concrete beams. In Proceedings of the 7th Int RILEM Symposium Fibre Reinforced Concretes: Design and Applicatons (BEFIB 2008), Chennai, India, 17-19 September 2008.

33. Kurtz, S.; Balaguru, P. Postcrack creep of polymeric fibre-reinforced concrete in flexure. Cem. Concr. Res. 2000, 30, 183-190. [CrossRef]

34. García-Taengua, E.; Arango, S.; Martì-Vargas, J.R.; Serna-Ros, P. A unified view on the effect of fibres and loading on SFRC creep through linear projection to latent structures. In Proceedings of the VIII International Conference on Fracture Mechanics of Concrete and Concrete Structures (FraMCoS-8), Toledo, Spain, 10-14 March 2013.

35. Monetti, D.H.; Llano-Torre, A.; Torrijos, M.C.; Giaccio, G.; Zerbino, R.; Martí-Vargas, J.R.; Serna, P. Long-term behavior of cracked fiber reinforced concrete under service conditions. Constr. Build Mater. 2019, 196, 649-658. [CrossRef]

36. Plizzari, G.; Serna, P. Structural effects of FRC creep. Mater. Struct. 2018, 51, 1-11. [CrossRef]

37. Italian Board of Standardization (UNI). UNI EN 11037. Fibre di Acciaio da Impiegare Nel Confezionamento di Conglomerato CEMENTIZIO rinforzato; Italian Board of Standardization (UNI): Milano, Italy, 2003.

38. Italian Board of Standardization (UNI). UNI EN 206-1 2001 Concrete-Specification, Performance, Production and Conformity; Italian Board of Standardization (UNI): Milano, Italy, 2001.

39. International Organization for Standardization. ISO 6784-International Standard-Concrete-Determination of Static Modulus of Elasticity in Compression; International Organization for Standardization: Geneva, Switzerland, 1982. 
40. International Organization for Standardization. EN 14651-Test Method for Metallic Fibre Concrete-Measuring the Flexural Tensile Strength (Limit of Proportionality (LOP), Residual); International Organization for Standardization: Geneva, Switzerland, 2007.

41. Swamy, R.N.; Sa'ad, A. Deformation and ultimate strength in flexure of reinforced concrete beams made with steel fiber concrete. J. Proc. 1981, 78, 395-405.

42. Tan, K.H.; Paramasivam, P.; Tan, K.C. Instantaneous and long-term deflections of steel fiber reinforced concrete beams. ACI Struct. J. 1994, 91, 384-393.

43. Abdul-Ahad, R.B.; Aziz, O.Q. Flexural strength of reinforced concrete T-beams with steel fibers. Cem. Concr. Compos. 1999, 21, 263-268. [CrossRef]

44. Meira, G.R.; Andrade, C.; Padaratz, I.J.; Alonso, C.; Borba, J.C. Chloride penetration into concrete structures in the marine atmosphere zone-relationship between deposition of chlorides on the wet candle and chlorides accumulated into concrete. Cem. Concr. Compos. 2007, 29, 667-676. [CrossRef]

45. Vasanelli, E.; Micelli, F.; Aiello, M.A. Influence of matrix grade on the mechanical behaviour of fibre-reinforced concrete. Proc. Inst. Civil Eng. Constr. Mater. 2014, 167, 258-270. [CrossRef]

46. Tuutti, K. Corrosion of Steel in Concrete; Royal Institute of Technology: Stockholm, Sweden, 1982.

(C) 2019 by the authors. Licensee MDPI, Basel, Switzerland. This article is an open access article distributed under the terms and conditions of the Creative Commons Attribution (CC BY) license (http://creativecommons.org/licenses/by/4.0/). 